\title{
25. AN ELECTRON MICROPROBE STUDY OF BASALT CHEMICAL VARIATION AT DEEP SEA DRILLING PROJECT SITES 482-485, GULF OF CALIFORNIA ${ }^{1}$
}

\author{
M. F. J. Flower, Department of Geological Sciences, University of Illinois, Chicago, Illinois \\ and \\ T. O'Hearn, Department of Mineral Sciences, Museum of Natural History, \\ Smithsonian Institution, Washington, D.C.
}

\section{INTRODUCTION}

Petrologic studies of mid-ocean ridge basalt (MORB) (e.g., Melson et al., 1975; Flower, et al., 1977; Byerly and Wright, 1978; Melson, 1979; Byerly and Sinton, 1980; Thompson, 1980) show that magmatic liquid-fraction trends are indicated by the compositions of fresh glass selvedges, usually, but not always, associated with pillow basalts. In contrast, whole-rock compositional variation will often reflect the complicating effects of syn- and post-eruptive phenocryst accumulation. Additional variation may be introduced by the reaction of basalts with seawater. While comparatively severe alteration of variable type was noted locally in the young basalts recovered across the mouth of the Gulf of California on Leg 65 , most of the basalts were extremely fresh, making them ideal for studies of compositional variation. The principal objectives of the present study are thus to use electron microprobe and XRF data as follows:

1) To define liquid compositional trends in basalts recovered from DSDP Sites $482-485$ on Leg 65 ;

2) To monitor chemical variation resulting from the cooling and crystallization of magmas during their uprise and emplacement;

3) To expand the existing data base for comparisons with other sampled parts of the ocean crust.

Placed in a chronologic perspective, such data should throw light on several broader problems concerning ocean-crust genesis at the comparatively fast-spreading East Pacific Rise (EPR). These include the thermal character and the nature of the magma supply of the EPR and comparisons between the EPR and the slowerspreading Mid-Atlantic Ridge (MAR). Three of the four sites (i.e., Sites 482,483 , and 485 ) form an approximate transect across the EPR parallel to the Tamayo Fracture Zone, while the fourth (Site 484) is located in the fracture zone itself.

\section{DATA COVERAGE}

The samples for this study were taken on board the Glomar Challenger during DSDP Leg 65 to supplement shipboard investigations of the drill core. The investigations made on board included lithologic, chemical, and

\footnotetext{
${ }^{1}$ Lewis, B. T. R., Robinson, P., et al., Init, Repts. DSDP, 65: Washington (U.S. Govt. Printing Office).
}

paleomagnetic studies and have been summarized elsewhere (site summaries, this volume). The results of shorebased electron microprobe studies on whole-rock and glass samples are presented here and interpreted within the framework defined by shipboard investigations.

Figure 1 depicts the major sections drilled during Leg 65 (Site 484 omitted) from which samples were taken for this study. As a result of variable sedimentation rates (increasing from west to east), the effective penetration of igneous basement was greatest at Site 483, west of the ridge axis, although this was not the deepest section. Sedimentary intercalations are thickest at Site 485 , possibly making this the least representative basement section despite its greater depth. At Site 483 (Holes A and B) three major types of igneous emplacement units are evident: "upper" (thick) massive units and "lower" (thin) massive units-the latter interlayered with the third type, pillow lavas. Magnetic and sediment stratigraphic considerations (see site summary, Site 483) suggest that the upper massive units represent a distinct late stage of crustal construction. The distinction may also be made on chemical grounds. If Site 483 is representative of both east- and west-spreading crust, it is reasonable to assume that seven (or more) massive units at Site 485 and the numerous massive units at Site 482 are equivalent to the five upper massive units at Site 483 . Samples were taken from each unit type, as shown in Figure 1.

The major element analyses obtained for glass and whole-rock samples (Tables 1,2) complement the shipboard analytical program, which, as a result of time constraints, omitted units in Holes 482B and $\mathrm{C}$ and the lower part of Hole 485A. Supplementary whole-rock sampling had the dual objective of completing a comprehensive data set and providing a basis for comparing results from the fused-bead electron microprobe technique used in this work and the X-ray fluorescence (XRF) method used on shipboard. The data for glass and "fused bead" whole-rock samples are given in Table 2, while sample listings in the appendix to this chapter cross-reference our sample numbers with DSDP sample numbers. Chemical Type averages based on microprobe and XRF techniques are given in Table 3.

\section{ANALYTICAL TECHNIQUES}

Analyses were made using a 9-spectrometer automated ARLSEMQ electron microprobe equipped with a wavelength-dispersive detector. Fresh natural glass samples were mounted and polished, ten 


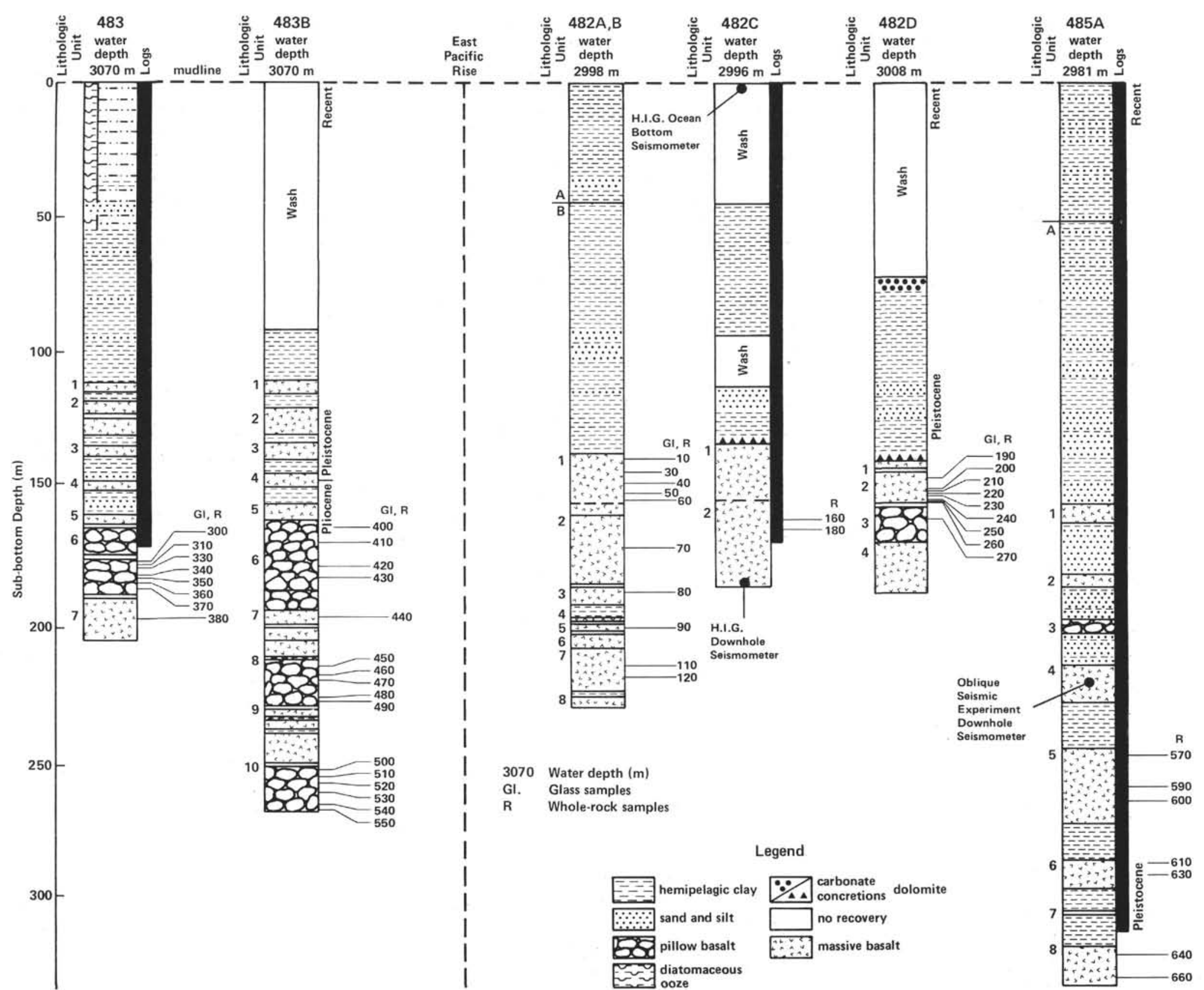

Figure 1. Lithologic columns of basement sections drilled during DSDP Leg 65, showing locations of samples used in this study and chief lithologic divisions. 
Table 1. Glass selvedges analyzed by electron microprobe (wt. \%).

\begin{tabular}{|c|c|c|c|c|c|c|c|c|c|c|c|c|c|c|c|c|c|c|c|c|c|c|c|c|c|c|c|c|c|}
\hline \multicolumn{30}{|c|}{ Reference No. $^{a}$} \\
\hline Oxide & 30 & so. & 210 & 220. & 230 & 250 & 260 & 290 & 310 & 330 & 340 & 350 & 360. & 370 & 400 & 410 & 420 & 430 & 450 & 460 & 470 & 480 & 490 & 500 & 510 & 520 & 530 & 540 & 550 \\
\hline & 50.90 & 50.14 & 50.09 & 50.09 & 50.63 & 50.71 & 51.38 & 50.76 & 49.46 & 49.89 & 51.11 & 50.75 & 50.69 & 50.46 & 50.29 & 50.01 & 50.16 & 50.73 & 50.09 & 50.21 & 49.93 & 49.87 & 50.32 & 50.40 & 50.77 & 50.58 & 50.27 & 50.77 & 50.74 \\
\hline & & .34 & 14.30 & & & & & 14.61 & 13.72 & 13.74 & 14.13 & .34 & 14.48 & 14.02 & 14.10 & 14.03 & 13.95 & 14.17 & 13.95 & 14.03 & 14.01 & 13.88 & & 13.93 & 14.11 & $14.10^{\circ}$ & 14.37 & 14.56 & 14.50 \\
\hline & & 2.34 & & 2.33 & & & & 2.35 & 2.61 & 2.58 & 2.50 & 2.50 & 2.51 & 2.71 & 2.55 & 2.60 & 2.64 & 2.70 & 2.60 & 2.60 & 2.60 & $2.58^{\circ}$ & 2.70 & 2.57 & 2.55 & 2.54 & 2.40 & 2.40 & 2.37 \\
\hline & & 8.47 & & & & & & 8.50 & 9.43 & 9.32 & & & & 9.79 & 9.21 & & 9.5 & & & & & & & & 9.22 & .17 & & 8.64 & 8.58 \\
\hline & 7.50 & 7.30 & 7.38 & & & 7.3 & 7.3 & 7.32 & 6.62 & & 7. & 7.08 & 7.11 & & & & 6. & & & 6.89 & & & & & & & & & 7.30 \\
\hline $\mathrm{CaO}$ & 12.25 & 12.16 & 12.14 & & & & 12.21 & 12.14 & 11.25 & 11.44 & 11. & 11.8 & 11.69 & & 11.82 & 11. & 11.36 & 11.46 & 11.50 & 11.68 & 11.59 & 11.62 & & 11.63 & & & & & 12.09 \\
\hline 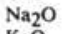 & & 2.52 & & & & & & 2.47 & 2.65 & & & & & & & & & & & & & & & & & & & & 2.55 \\
\hline & & 0.08 & 0.08 & & & & & 0.08 & 0.09 & & & & & & & & & & & & & & & & & & & & 0.09 \\
\hline & & 1.52 & 1.52 & & & & & & & & & & & & & & & & & & & & & & & & & & 1.71 \\
\hline $\mathrm{P}_{2} \mathrm{O}_{5}$ & 0.13 & 0.12 & 0.12 & 0.13 & 0.14 & 0.13 & 0.13 & 0.14 & 0.19 & 0.17 & 0.16 & 0.19 & 0.17 & 0.22 & 0.13 & 0.18 & 0.21 & 0.18 & 0.18 & 0.18 & 0.19 & 0.16 & 0.18 & 0.17 & 0.15 & 0.18 & 0.17 & 0.18 & 0.16 \\
\hline Total & 100.41 & 98.99 & 98.83 & 99.13 & 100.14 & 99.89 & 100.67 & 99.87 & 98.00 & 98.42 & 100.40 & 100.22 & 100.21 & 99.83 & 99.58 & 99.27 & 99.41 & 100.60 & 99.04 & 99.68 & 99.00 & 98.82 & 99.35 & 99.46 & 100.20 & 99.59 & 99.34 & 100.24 & 100.09 \\
\hline \multicolumn{30}{|c|}{ CIPW Norm } \\
\hline & & & & & & & & & & & & & & 1.77 & & & & & & & & & & & & & & & \\
\hline & & & & & & & & & & & & & & & & & & & & & & & & & & & & & \\
\hline & & & 20.90 & & & & & & & & & & & & & 22 & & & & & & & 22 & & & & & & 21.58 \\
\hline & & & & & & & & & & & & & & & & & & & & & & & & & & & & & \\
\hline & & & & & & & & & & & & & & & & & & & & & & & & & & & & & \\
\hline H & & & 16 . & & & & & & & & & & & & & & & & & & & & & & & & & & \\
\hline M & & 3. & $3:$ & & & & & & & & & & & & & & & & & & & & & & & & & & 44 \\
\hline IL & & & & & & & & & & & & & & & & & & & & & & & & & & & & & \\
\hline AP & 0.30 & 0.28 & 0.28 & 0.30 & 0.32 & 0.30 & 0.30 & 0.32 & 0.44 & 0.39 & 0.37 & 0.44 & 0.39 & 0.51 & 0.30 & 0.42 & 0.49 & 0.42 & $0.4 z$ & 0.42 & 0.4 & 0.37 & 0.4 & 0.39 & 0.35 & 0.42 & 0.39 & 0.42 & 0.37 \\
\hline
\end{tabular}

${ }^{\text {a }}$ See appendix to this chapter for equivalent DSDP sample numbers. 
Table 2. Whole-rock samples analyzed as fused beads by electron microprobe (wt. \%).

\begin{tabular}{|c|c|c|c|c|c|c|c|c|c|c|c|c|c|c|c|c|c|c|c|c|c|c|c|c|c|c|}
\hline \multicolumn{27}{|c|}{ Reference $\mathrm{No}^{\mathrm{a}}$} \\
\hline Oxide & 10 & 10 & 40 & 40 & 60 & 60 & 70 & 70 & 80 & 80 & 90 & 90 & 100 & 100 & 110 & 110 & 120 & 120 & 160 & 160 & 180 & 180 & 190 & 190 & 200 & 200 \\
\hline $\mathrm{SiO}_{2}$ & 50.39 & 50.53 & 50.54 & 50.53 & 49.97 & 50.10 & 50.63 & 50.43 & 50.79 & 50.74 & 50.41 & 50.61 & 50.97 & 50.77 & 50.81 & 50.78 & 50.80 & 50.61 & 51.55 & 51.71 & 51.19 & 50.98 & 50.65 & 50.84 & 50.83 & 50.68 \\
\hline $\mathrm{Al}_{2} \mathrm{O}_{3}$ & 14.88 & 15.09 & 17.17 & 17.33 & 15.85 & 15.86 & 16.42 & 16.33 & 16.00 & 15.78 & 15.80 & 15.67 & 15.51 & 15.62 & 16.82 & 16.62 & 15.17 & 14.88 & 14.92 & 14.89 & 15.08 & 14.96 & 15.56 & 15.57 & 15.86 & 16.21 \\
\hline $\mathrm{Fe}_{2} \mathrm{O}_{3}$ & 2.35 & 2.30 & 2.10 & 2.04 & 2.21 & 2.21 & 2.28 & 2.20 & 2.13 & 2.20 & 2.24 & 2.23 & 2.27 & 2.30 & 2.05 & 2.14 & 2.38 & 2.38 & 2.23 & 2.27 & 2.24 & 2.24 & 2.27 & 2.27 & 2.17 & 2.14 \\
\hline $\mathrm{FeO}$ & 8.50 & 8.31 & 7.60 & 7.35 & 7.98 & 8.00 & 8.23 & 7.93 & 7.69 & 7.96 & 8.07 & 8.04 & 8.20 & 8.28 & 7.44 & 7.71 & 8.60 & 8.63 & 8.05 & 8.18 & 8.09 & 8.10 & 8.22 & 8.19 & 7.82 & 7.71 \\
\hline $\mathrm{MgO}$ & 7.38 & 7.48 & 7.65 & 7.56 & 7.94 & 7.92 & 8.21 & 8.09 & 8.49 & 8.03 & 7.52 & 7.54 & 7.46 & 7.66 & 7.91 & 7.99 & 8.00 & 7.89 & 7.94 & 7.87 & 7.76 & 7.95 & 8.08 & 8.03 & 8.17 & 8.35 \\
\hline $\mathrm{CaO}$ & 11.88 & $\begin{array}{l}1.40 \\
12.10\end{array}$ & 10.77 & 10.67 & 11.84 & 11.73 & 10.57 & 10.38 & 11.85 & 11.55 & 11.42 & 11.29 & 11.76 & 11.90 & 11.32 & 11.70 & 10.91 & 10.53 & 11.75 & 11.90 & 12.17 & 11.91 & 12.03 & 12.03 & 11.16 & 11.22 \\
\hline $\mathrm{Na}_{2} \mathrm{O}$ & 2.37 & 2.34 & 2.75 & 2.59 & 2.24 & 2.02 & 2.26 & 2.38 & 1.71 & 2.19 & 2.40 & 2.52 & 2.24 & 1.85 & 1.41 & 1.78 & 1.93 & 2.36 & 2.27 & 2.45 & 2.29 & 2.31 & 2.46 & 2.37 & 2.38 & 1.76 \\
\hline $\mathrm{K}_{2} \mathrm{O}$ & 0.08 & 0.11 & 0.07 & 0.06 & 0.06 & 0.07 & 0.09 & 0.08 & 0.03 & 0.09 & 0.05 & 0.05 & 0.04 & 0.02 & 0.02 & 0.04 & 0.04 & 0.07 & 0.07 & 0.06 & 0.07 & 0.09 & 0.08 & 0.09 & 0.07 & 0.06 \\
\hline $\mathrm{TiO}_{2}$ & 1.82 & 1.84 & 1.52 & 1.50 & 1.40 & 1.44 & 1.42 & 1.42 & 1.42 & 1.42 & 1.57 & 1.61 & 1.54 & 1.56 & 1.63 & 1.62 & 1.84 & 1.84 & 1.37 & 1.28 & 1.26 & 1.33 & 1.45 & 1.44 & 1.46 & 1.43 \\
\hline $\mathrm{P}_{2} \mathrm{O}_{5}$ & 0.16 & 0.16 & 0.11 & 0.10 & 0.13 & 0.11 & 0.11 & 0.12 & 0.06 & 0.10 & 0.14 & 0.14 & 0.10 & 0.12 & 0.10 & 0.08 & 0.10 & 0.15 & 0.14 & 0.12 & 0.10 & 0.13 & 0.13 & 0.12 & 0.11 & 0.07 \\
\hline
\end{tabular}

$\begin{array}{llllllllllllllllllllllllllll}\text { Total } & 99.81 & 100.26 & 100.28 & 99.73 & 99.62 & 99.46 & 100.22 & 99.36 & 100.17 & 100.06 & 99.62 & 99.70 & 100.09 & 100.08 & 99.51 & 100.46 & 99.77 & 99.34 & 100.29 & 100.73 & 100.25 & 100.00 & 100.93 & 100.95 & 100.03 & 99.63\end{array}$ CIPW Norm

\begin{tabular}{|c|c|c|c|c|c|c|c|c|c|c|c|c|c|c|c|c|c|c|c|c|c|c|c|c|c|c|}
\hline & 1.52 & 1.35 & & 0.76 & 0.45 & 1.74 & 1.35 & 1.27 & 3.15 & 1.57 & 1.33 & 1.19 & 2.42 & 3.65 & 6.00 & 3.47 & 3.99 & 2.41 & 2.44 & 1.53 & 1.54 & 1.32 & & 0.29 & 1.12 & 3.47 \\
\hline$\partial_{\mathrm{r}}$ & 0.47 & 0.65 & 0.41 & 0.35 & 0.35 & 0.41 & 0.53 & 0.47 & 0.18 & 0.53 & 0.30 & 0.30 & 0.24 & 0.12 & 0.12 & 0.24 & 0.24 & 0.41 & 0.41 & 0.35 & 0.41 & 0.53 & 0.47 & 0.53 & 0.41 & \\
\hline & 20.06 & 19.80 & 23.27 & 21.92 & 18.96 & 17.09 & 19.12 & 20.14 & 14.47 & 18.53 & 20.31 & 21.32 & 18.96 & 15.65 & 11.93 & 15.06 & 16.33 & 19.97 & 19.21 & 20.73 & 19.38 & 19.55 & 20.82 & 20.06 & 20.14 & \\
\hline & 29.73 & .35 & 4.30 & 35.49 & 33.02 & 34.00 & & 33.64 & & 32.96 & 32.19 & 31.30 & 32.15 & 34.26 & 39.51 & 37.24 & 32.61 & 29.80 & 30.32 & 29. & 30.66 & 30.19 & 31.18 & 58 & 32.39 & \\
\hline & & & 92 & 13.6 & 20 & 19 & 14.0 & 13.8 & & 19.2 & 19.1 & 19. & 20. & 9 & 12. & & & & 1. & 23. & & & 22. & & 2 & \\
\hline $\mathrm{H}$ & 17.90 & 17.6 & $\begin{array}{r}20.29 \\
0.90\end{array}$ & 21.58 & 20.50 & 20.97 & 24.51 & 23.84 & 22.36 & 21.14 & 19.81 & 19.66 & 19.12 & 20.33 & 22.72 & 21.67 & 22.49 & 22.03 & 19.79 & 19.26 & 18.77 & 19.57 & $\begin{array}{r}18.67 \\
100\end{array}$ & 20.02 & 21.77 & \\
\hline & & & & & & & & & & & & & & & & & & & & & & & & & & \\
\hline & 0.37 & & & 2.8 & & & & & & & & & & & & & 3. & & & & & & & & & \\
\hline & & 0.37 & 0.25 & 0.23 & 0.30 & 0.25 & 0.25 & 0.28 & 0.14 & 0.23 & 0.32 & 0.32 & 0.23 & 0.28 & 0.23 & 0.19 & 0.23 & 0.35 & 0.32 & 0.28 & 0.23 & 0.30 & 0.30 & 0.28 & 0.25 & \\
\hline
\end{tabular}

${ }^{\text {a }}$ See appendix to this chapter for equivalent DSDP sample numbers.

Table 2. (Continued).

\begin{tabular}{|c|c|c|c|c|c|c|c|c|c|c|c|c|c|c|c|c|c|c|c|c|c|c|c|c|}
\hline \multirow[b]{2}{*}{ Oxide } & \multirow[b]{2}{*}{240} & \multicolumn{23}{|c|}{ Reference $\mathrm{No}^{\mathrm{a}}$} \\
\hline & & 240 & 270 & 270 & 300 & 300 & 380 & 380 & 440 & 440 & 570 & 570 & 590 & 590 & 600 & 600 & 610 & 610 & 630 & 630 & 640 & 640 & 660 & 660 \\
\hline $\mathrm{SiO}_{2}$ & 50.48 & 50.28 & 50.90 & 51.10 & 50.86 & 50.72 & 50.15 & 50.27 & 50.13 & 49.97 & 50.20 & 50.16 & 50.29 & 50.47 & 50.30 & 49.93 & 51.02 & 51.16 & 50.98 & 50.29 & 51.01 & 50.89 & 50.49 & 50.42 \\
\hline $\mathrm{Al}_{2} \mathrm{O}_{3}$ & 15.60 & 15.53 & 15.09 & 15.38 & 18.53 & 18.43 & 15.91 & 15.88 & 14.22 & 14.35 & 15.43 & 15.21 & 14.88 & 15.03 & 14.71 & 14.52 & 14.69 & 15.02 & 14.58 & 14.40 & 15.50 & 15.32 & 16.11 & 16.14 \\
\hline $\mathrm{Fe}_{2} \mathrm{O}_{3}$ & 2.25 & $\begin{array}{l}2.30 \\
0\end{array}$ & 2.25 & 2.20 & 1.74 & 1.78 & 2.48 & 2.45 & 2.70 & 2.71 & 2.50 & 2.48 & 2.64 & 2.63 & 2.64 & 2.73 & 2.48 & 2.41 & 2.50 & 2.50 & 2.41 & 2.41 & 2.27 & 2.38 \\
\hline $\mathrm{FeO}$ & 8.14 & 8.28 & 8.14 & 7.95 & 6.31 & 6.43 & 8.95 & 8.88 & 9.72 & 9.77 & 9.01 & 8.99 & 9.53 & 9.49 & 9.52 & 9.84 & 8.99 & 8.72 & 9.03 & 9.01 & 8.72 & 8.70 & 8.22 & 8.60 \\
\hline $\mathrm{MgO}$ & 8.01 & 8.03 & 8.26 & 8.35 & 7.84 & 7.89 & 7.23 & 7.17 & 7.22 & 7.24 & 8.06 & 8.16 & 7.47 & 7.46 & 7.52 & 7.37 & 7.81 & 7.71 & 7.38 & 7.50 & 7.28 & 7.45 & 7.15 & 7.37 \\
\hline $\mathrm{CaO}$ & 11.85 & 12.03 & 12.20 & 12.22 & 12.03 & 12.09 & 11.12 & 11.20 & 10.93 & 10.97 & 11.03 & 11.06 & 10.69 & 10.62 & 11.49 & 11.40 & 11.25 & 11.15 & 12.04 & 12.02 & 11.19 & 11.26 & 11.52 & 11.99 \\
\hline $\mathrm{Na}_{2} \mathrm{O}$ & 2.31 & 2.28 & 2.08 & 1.72 & 2.57 & 2.67 & 2.49 & 2.50 & 2.61 & 2.25 & 2.51 & 2.45 & 2.49 & 2.41 & 1.75 & 2.52 & 2.52 & 2.57 & 2.48 & 2.20 & 2.57 & 2.13 & 1.93 & 1.79 \\
\hline $\mathrm{K}_{2} \mathrm{O}$ & 0.09 & 0.10 & 0.06 & 0.05 & 0.07 & 0.10 & 0.07 & 0.07 & 0.09 & 0.08 & 0.17 & 0.17 & 0.19 & 0.18 & 0.16 & 0.21 & 0.09 & 0.09 & 0.09 & 0.10 & 0.09 & 0.11 & 0.07 & 0.07 \\
\hline $\mathrm{TiO}_{2}$ & 1.42 & 1.39 & 1.34 & 1.28 & 1.06 & 1.05 & 2.21 & 2.17 & 2.30 & 2.16 & 1.82 & 1.89 & 2.22 & 2.17 & 2.15 & 2.19 & 1.85 & 1.85 & 1.86 & 1.83 & 1.87 & 1.91 & 1.67 & 1.70 \\
\hline $\mathrm{P}_{2} \mathrm{O}_{5}$ & 0.12 & 0.13 & 0.11 & 0.08 & 0.12 & 0.13 & 0.18 & 0.18 & 0.19 & 0.17 & 0.17 & 0.15 & 0.18 & 0.19 & 0.09 & 0.18 & 0.14 & 0.20 & 0.13 & 0.17 & 0.17 & 0.18 & 0.12 & 0.11 \\
\hline \multirow[t]{2}{*}{ Total } & 100.27 & 100.35 & 100.43 & 100.33 & 101.13 & 101.29 & 100.79 & 100.77 & 100.11 & 99.67 & 100.90 & 100.72 & 100.58 & 100.65 & 100.33 & 100.89 & 100.84 & 100.88 & 101.07 & 100.02 & 100.81 & 100.36 & 99.55 & 100.57 \\
\hline & \multicolumn{24}{|c|}{ CIPW Norm } \\
\hline Q & 0.44 & 0.07 & 1.55 & 3.25 & & & 1.15 & 1.26 & 1.22 & 2.52 & & & 1.20 & 1.81 & 3.89 & & 1.17 & 1.41 & 1.15 & 1.78 & & & & \\
\hline Or & 0.53 & 0.59 & 0.35 & 0.30 & 0.41 & 0.59 & 0.41 & 0.41 & 0.53 & 0.47 & 1.00 & 1.00 & 1.12 & 1.06 & 0.95 & 1.24 & 0.53 & 0.53 & 0.53 & 0.59 & 1.55 & 3.34 & 3.82 & 3.31 \\
\hline$A b$ & 19.55 & 19.29 & 17.60 & 14.55 & 21.75 & 22.59 & 21.07 & 21.16 & 22.09 & 19.04 & 21.24 & 20.73 & 21.07 & 20.39 & 14.81 & 21.32 & 21.32 & 21.75 & 20.99 & 18.62 & 0.53 & 0.65 & 0.41 & 0.41 \\
\hline An & 31.93 & 31.85 & 31.66 & 34.10 & 38.82 & 38.01 & 32.03 & 31.90 & 26.82 & 28.82 & 30.33 & 30.00 & 28.86 & 29.66 & 31.81 & 27.69 & 28.51 & 29.18 & 28.39 & 29.12 & 21.75 & 18.02 & 16.33 & 15.15 \\
\hline $\mathrm{Di}$ & 21.16 & 21.91 & 22.83 & 21.07 & 16.19 & 17.04 & 17.87 & 18.30 & 21.36 & 20.01 & 18.92 & 19.40 & 18.74 & 17.76 & 20.05 & 22.61 & 21.47 & 20.18 & 24.85 & 23.95 & 30.49 & 31.92 & 35.09 & 35.80 \\
\hline $\mathrm{Hy}$ & 20.42 & 20.36 & 20.37 & 21.25 & 16.61 & 13.36 & 20.04 & 19.64 & 19.37 & 20.39 & 20.81 & 21.55 & 21.12 & 21.59 & 20.70 & 19.45 & 20.41 & 20.35 & 17.71 & 18.46 & 19.47 & 18.52 & 17.31 & 18.69 \\
\hline oi & & & & & 2.53 & 4.82 & & & & & 1.12 & 0.50 & & & & 0.04 & & & & & 19.58 & 20.37 & 19.84 & 20.27 \\
\hline Mt & 3.26 & 3.33 & 3.2 & 3.15 & 2.52 & 2.58 & 3.6 & 3.55 & 3.9 & 3.9 & 3.62 & 3.6 & 3.8 & 3.8 & 3.8 & 3.5 & 3.60 & 3.4 & 3.62 & 3.6 & 3.49 & 3.49 & 3.29 & 3.45 \\
\hline II & 2.70 & & & 2.4 & 2.01 & 1.9 & 4.2 & 4.1 & 4.3 & 4.10 & 3.4 & 3. & 4.2 & 4.1 & 4.0 & 4.1 & 3.5 & 3.5 & & 3.4 & 3.5 & 3.63 & 3.17 & 3.23 \\
\hline Ap & 0.28 & 0.30 & 0.25 & 0.19 & 0.28 & 0.30 & 0.42 & 0.42 & 0.44 & 0.39 & 0.39 & 0.35 & 0.42 & 0.44 & 0.21 & 0.42 & 0.32 & 0.46 & 0.30 & 0.39 & 0.39 & 0.42 & 0.28 & 0.25 \\
\hline
\end{tabular}


Table 3. Average chemical type compositions for Sites $482-485$ based on (a) electron-microprobe analyses of fused beads, (b) X-ray fluorescence data, and (c) shipboard X-ray fluorescence data.

\begin{tabular}{|c|c|c|c|c|c|c|c|c|c|c|c|}
\hline \multirow{2}{*}{$\begin{array}{c}\text { Chemical } \\
\text { Type }\end{array}$} & \multicolumn{11}{|c|}{ Oxides } \\
\hline & $\mathrm{SiO}_{2}$ & $\mathrm{Al}_{2} \mathrm{O}_{3}$ & $\mathrm{FeO} *$ & $\mathrm{MgO}$ & $\mathrm{CaO}$ & $\mathrm{Na}_{2} \mathrm{O}$ & $\mathrm{K}_{2} \mathrm{O}$ & $\mathrm{TiO}_{2}$ & $\mathrm{P}_{2} \mathrm{O}_{5}$ & $\mathrm{MnO}$ & $n$ \\
\hline \multicolumn{12}{|l|}{ Site 482} \\
\hline \multirow[t]{3}{*}{ A } & a: 50.46 & 14.99 & 10.52 & 7.43 & 11.99 & 2.36 & 0.10 & 1.83 & 0.14 & - & 2 \\
\hline & b: 50.41 & 14.59 & 10.22 & 7.91 & 12.08 & 2.53 & 0.09 & 1.80 & 0.16 & 0.22 & 1 \\
\hline & c: 50.73 & 14.65 & 10.84 & 7.85 & 11.56 & 2.28 & 0.06 & 1.86 & 0.18 & - & 11 \\
\hline \multirow[t]{3}{*}{ B } & a: 50.81 & 15.61 & 10.05 & 8.02 & 11.86 & 2.21 & 0.07 & 1.32 & 0.11 & - & 10 \\
\hline & b: 50.48 & 15.01 & 9.96 & 8.09 & 12.13 & 2.46 & 0.05 & 1.38 & 0.11 & 0.18 & 1 \\
\hline & c: 50.91 & 14.79 & 10.37 & 8.15 & 12.16 & 2.13 & 0.04 & 1.34 & 0.12 & - & 22 \\
\hline \multirow[t]{3}{*}{ D } & a: 50.67 & 15.83 & 10.12 & 7.81 & 11.20 & 2.07 & 0.05 & 1.69 & 0.12 & - & 6 \\
\hline & b: 50.34 & 15.42 & 9.92 & 7.41 & 12.35 & 2.63 & 0.04 & 1.56 & 0.14 & 0.18 & 1 \\
\hline & c: 50.85 & 15.86 & 9.74 & 7.30 & 12.01 & 2.43 & 0.04 & 1.62 & 0.15 & - & 4 \\
\hline \multirow[t]{3}{*}{$\mathrm{E}$} & a: 50.81 & 15.57 & 10.31 & 7.81 & 11.93 & 2.24 & 0.06 & 1.80 & 0.12 & - & 4 \\
\hline & b: 50.62 & 14.58 & 10.38 & 7.78 & 11.68 & 2.69 & 0.06 & 1.89 & 0.16 & 0.17 & 1 \\
\hline & c: 50.68 & 14.36 & 10.86 & 7.86 & 11.62 & 2.52 & 0.05 & 1.89 & 0.17 & - & 4 \\
\hline \multirow[t]{3}{*}{$\mathrm{F}$} & a: 50.68 & 16.28 & 9.79 & 7.98 & 11.31 & 2.38 & 0.08 & 1.47 & 0.12 & - & 6 \\
\hline & b: 50.38 & 15.02 & 10.09 & 8.20 & 12.06 & 2.47 & 0.06 & 1.43 & 0.11 & 0.18 & 1 \\
\hline & c: 50.50 & 14.99 & 10.35 & 8.02 & 12.07 & 2.37 & 0.05 & 1.52 & 0.13 & - & 5 \\
\hline \multicolumn{12}{|l|}{ Site 483} \\
\hline \multirow[t]{3}{*}{ D } & a: 50.79 & 18.48 & 7.98 & 7.87 & 12.06 & 2.62 & 0.08 & 1.06 & 0.13 & - & 2 \\
\hline & b: 49.66 & 16.81 & 8.25 & 9.06 & 12.66 & 2.27 & 0.04 & 1.01 & 0.07 & 0.16 & 1 \\
\hline & c: 49.43 & 16.53 & 8.76 & 9.59 & 12.49 & 2.10 & 0.02 & 0.98 & 0.09 & - & 5 \\
\hline \multirow[t]{3}{*}{$\mathrm{H}$} & a: 50.13 & 15.10 & 11.69 & 7.22 & 11.06 & 2.47 & 0.08 & 2.21 & 0.18 & - & 2 \\
\hline & b: 50.19 & 14.51 & 11.34 & 7.24 & 11.27 & 2.79 & 0.09 & 2.17 & 0.20 & 0.19 & 1 \\
\hline & c: 50.37 & 14.38 & 11.76 & 7.12 & 11.23 & 2.65 & 0.08 & 2.22 & 0.21 & - & 12 \\
\hline \multicolumn{12}{|l|}{ Site 485} \\
\hline \multirow[t]{3}{*}{$\mathrm{I}(\mathrm{S})$} & a: 50.18 & 15.32 & 11.27 & 8.11 & 11.05 & 2.48 & 0.17 & 1.86 & 0.16 & - & 1 \\
\hline & b: 49.58 & 14.90 & 11.52 & 7.98 & 10.75 & 2.67 & 0.15 & 2.06 & 0.19 & 0.20 & 4 \\
\hline & c: 50.41 & 14.16 & 11.74 & 7.56 & 11.28 & 2.42 & 0.09 & 2.15 & 0.19 & - & 3 \\
\hline \multirow[t]{3}{*}{ I(T) } & a: 50.25 & 14.79 & 12.01 & 7.46 & 11.05 & 2.29 & 0.19 & 2.18 & 0.18 & - & 4 \\
\hline & b: 49.84 & 14.54 & 11.79 & 7.76 & 10.75 & 2.56 & 0.18 & 2.17 & 0.20 & 0.21 & 5 \\
\hline & c: 50.12 & 14.60 & 12.02 & 7.41 & 11.01 & 2.28 & 0.18 & 2.20 & 0.18 & - & 2 \\
\hline \multirow[t]{3}{*}{$\mathbf{J}$} & a: 50.86 & 14.67 & 11.19 & 7.67 & 11.62 & 2.44 & 0.09 & 1.85 & 0.16 & - & 4 \\
\hline & b: 50.79 & 14.74 & 10.69 & 7.76 & 11.55 & 2.25 & 0.10 & 1.79 & 0.15 & 0.18 & 7 \\
\hline & $\mathrm{c}:-$ & $=$ & - & - & - & - & - & - & - & - & - \\
\hline \multirow[t]{3}{*}{ L } & a: 50.70 & 15.77 & 10.72 & 7.31 & 11.49 & 2.11 & 0.09 & 1.79 & 0.15 & - & 4 \\
\hline & b: 50.57 & 14.98 & 10.71 & 7.65 & 11.23 & 2.58 & 0.06 & 1.87 & 0.16 & 0.19 & 4 \\
\hline & c: - & - & - & - & - & - & - & - & - & - & - \\
\hline
\end{tabular}

per 1-in. plastic disc, and analyzed using the following: a sample current of $0.05 \mu \mathrm{A}$, an accelerating potential of $15 \mathrm{kV}$, and a (defocussed) beam size of $20-50 \mu \mathrm{m}$. Each sample was analyzed between four and eight times using a 10-s count for each analysis, the data being averaged and corrected for matrix effects using the method of Bence and Albee (1968). In addition to these corrections, the results were normalized after every 10 analyses to a basaltic glass standard (USNM $113716)$ mounted in the center of the disc.

The method of Jezek et al. (1979) was used to prepare synthetic fused glass for analysis of whole-rock samples. Whole-rock samples were ground in agate to finer than 100 mesh, and replicate powders were fused in 2-cm-long molybdenum boats in a nitrogen atmosphere. Fusion was accomplished using a fusion bridge powered by a $1.5 \mathrm{kVA}$ welding transformer. For each fusion, the sample assembly was covered by a bell jar and flushed with nitrogen. It was then heated to dark red-heat for $10 \mathrm{~s}$ to drive off adsorbed water, then to about $1700^{\circ} \mathrm{C}$ for $10-30 \mathrm{~s}$ to promote formation of homogeneous glass. A fused bead formed, which was quenched by cutting power to the fusion bridge and directing a stream of nitrogen to the base of the fusion boat. Glass fragments not in contact with the molybdenum boat were then analyzed by electron microprobe using the same operating conditions as for natural glass.

Jezek et al. (1979) observed relatively poor accuracy for $\mathrm{TiO}_{2}$ using this technique, possibly because of residual iron-titanium oxide in some glass samples. This problem was not encountered in the present work, although residual plagioclase was noted in a few beads. The correspondence between replicate analyses is acceptable and in most cases excellent. It seems likely that analytical quality could be improved by reducing the initial sample to 200 mesh.

Twenty-nine glass selvedge and 25 whole-rock glass beads were analyzed, the latter in replicate. The data are listed in Table 2 , with calculated CIPW norms.

\section{GLASS COMPOSITIONS}

\section{Site 482 (Holes 482B, D, and F)}

Eight glass analyses from Site 482 (Holes B, D, and F) are plotted in Figure 2 according to whole-rock chemical types defined on shipboard (see site summaries, this volume) and reviewed by Flower et al. (this volume). Most belong to Type $\mathrm{F}$ and a few to Type B; one analysis from Hole $482 \mathrm{~F}$ does not correspond to either of these. The glass variation is considerably less than the whole-rock variation for these chemical types. Discrepancies between whole-rock and glass chemistry for single cooling units (shown by tie lines in Fig. 2) indicate that intracooling unit variation may be greater than the overall variation of the liquid fraction. The latter is by no means well represented by glass, however. Glass is comparatively sparse at this site since no pillow sequences were encountered. Aphyric Chemical Types A and E based on shipboard analyses are outlined in Figure 2 to indicate the range and type (e.g., note $\mathrm{TiO}_{2}$ and $\mathrm{P}_{2} \mathrm{O}_{5}$ ) of liquid variation observed in the basalts from this site.

The tie-line variation indicates that intraunit fractionation is of "liquid-fractionation" type and does not reflect the accumulation of phenocrysts. Analogous fractionation trends are shown by the whole-rock compositions of Chemical Types A and E (Fig. 2). 

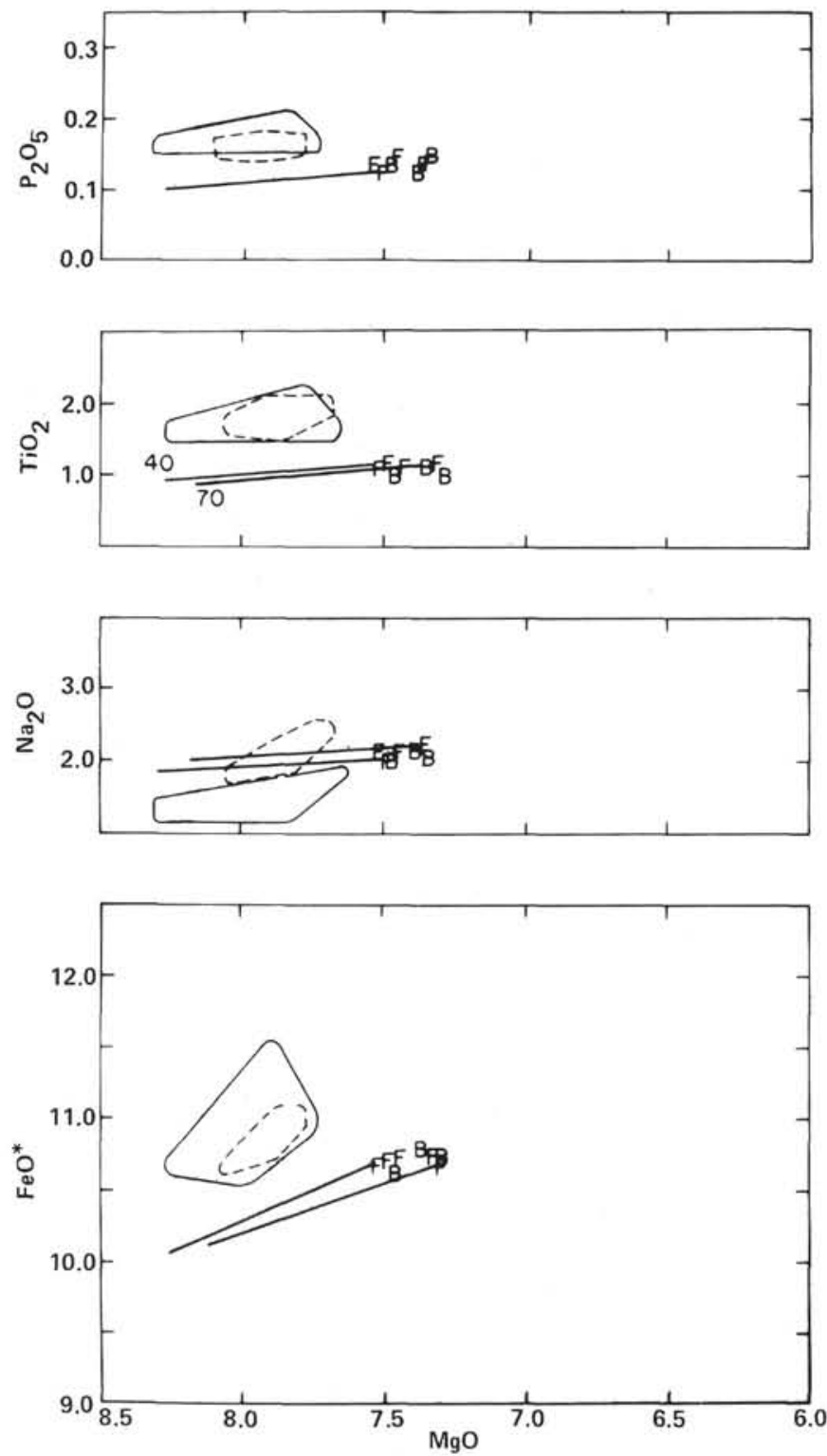
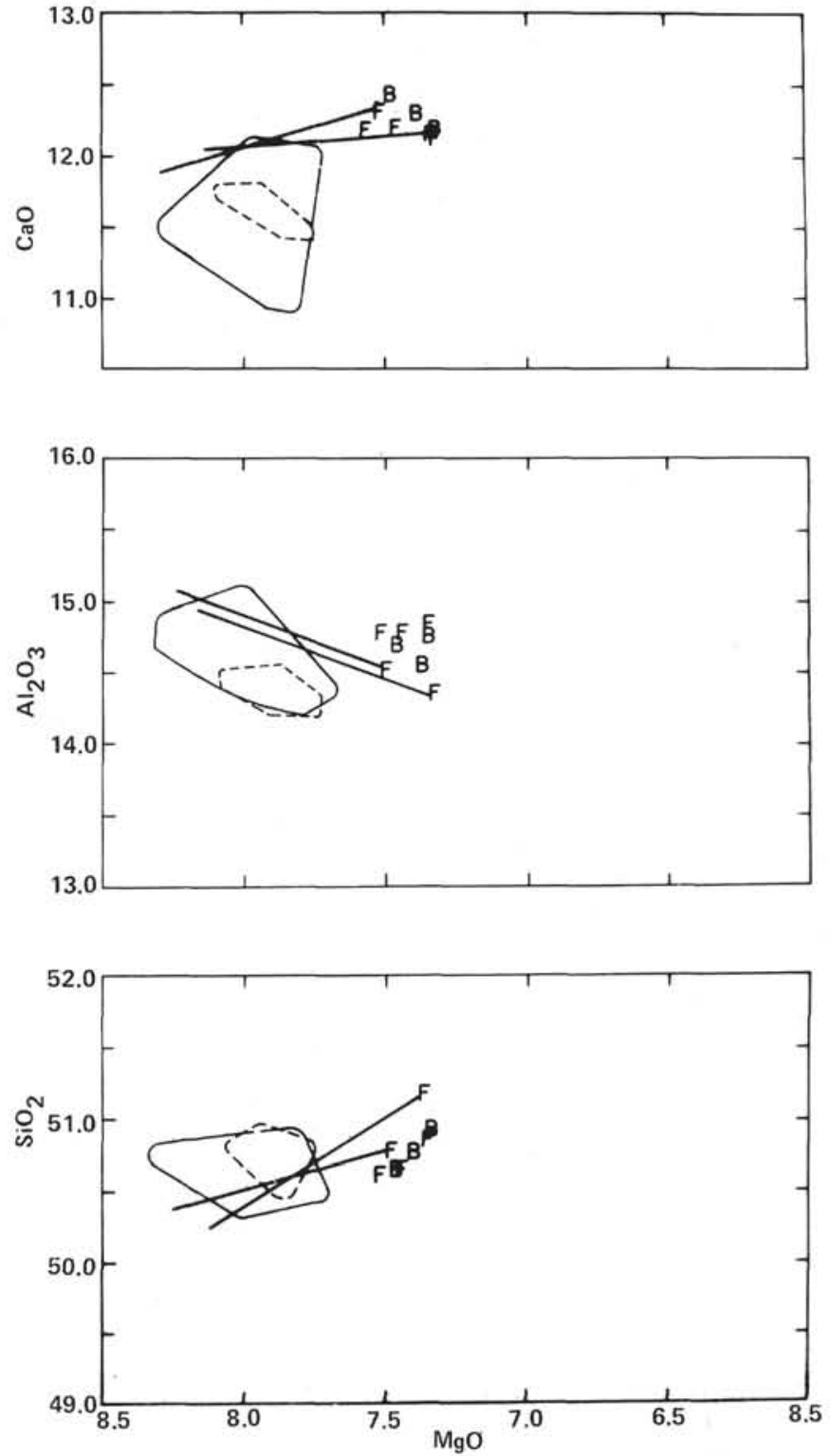

Figure 2. Oxide (wt.\%) versus $\mathrm{MgO}$ variations of glass samples plotted according to equivalent whole-rock chemical type, Site 482 . (Tie-lines connect glass to whole-rock compositions for equivalent cooling units. Variation of shipboard whole-rock Chemical Types A (solid line) and E (dashed line) is shown in outline for comparison.)

\section{Site 483 (Holes 483 and 483B)}

The glass data for Site 483 reflect more extensive fractionation than the Site 482 glass compositions. The former represent cooling selvedges of pillow lava sequences (whole-rock Chemical Types F, J, L, and M), while the latter represent the cooling rinds of the "upper" massive units. The more fractionated nature of the Site 483 glass is thus consistent with the observation that the "upper" massive unit whole-rock compositions are generally more primitive than the "lower" massive and pillow lavas at the same site. The Site 483 glass trend (Fig. 3) reflects an increase in $\mathrm{FeO}^{*}$ (i.e., total iron oxides), $\mathrm{TiO}_{2}, \mathrm{P}_{2} \mathrm{O}_{5}$, and $\mathrm{Na}_{2} \mathrm{O}$, and a decrease in $\mathrm{CaO}$ and
$\mathrm{Al}_{2} \mathrm{O}_{3}$ with decreasing $\mathrm{MgO}$. This trend is consistent with simple fractional crystallization of olivine, plagioclase, and clinopyroxene (cf. Bryan et al. 1979) as confirmed by least squares analysis of the variation (Flower et al., this volume). Whole-rock/glass single-cooling unit pairs are also shown by tie-lines in Figure 3. These contrast slightly with the overall liquid trend (note $\mathrm{Al}_{2} \mathrm{O}_{3}$ and $\mathrm{SiO}_{2}$ ) and suggest that some phenocryst accumulation, principally of plagioclase, has occurred in these units.

From the available evidence, we may conclude that most of the liquid fraction compositions erupted at Sites 482 and 483 were slightly to moderately evolved. While the pillow liquid compositions are well represented by 

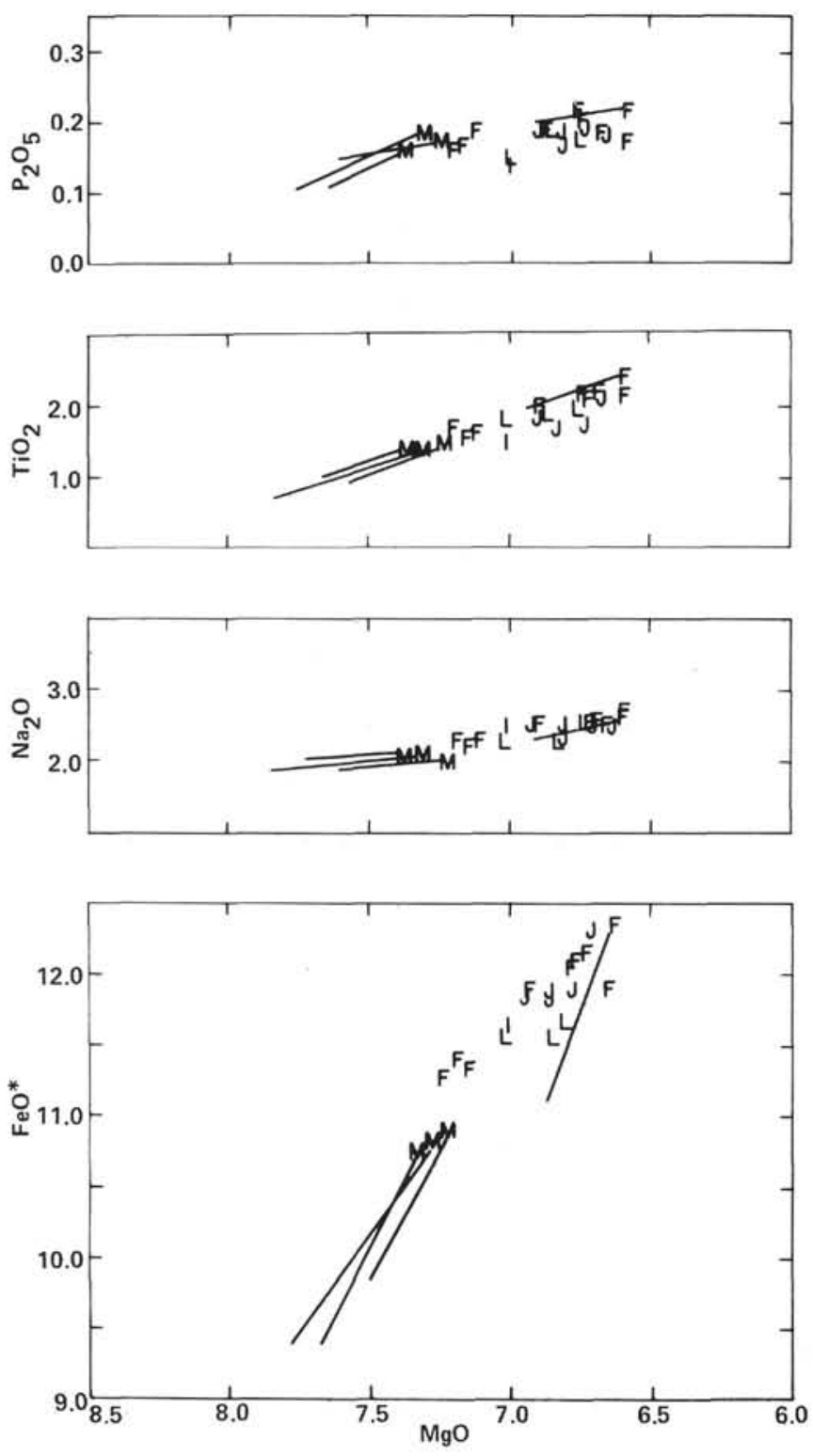

Figure 3. Oxide (wt.\%) versus $\mathrm{MgO}$ variations of glass samples plotted nect glass to whole-rock compositions for equivalent cooling units.)

glass, those for the upper and lower massive units are unfortunately not well represented, except by aphyric whole-rock compositions.

\section{WHOLE-ROCK FUSED BEAD DATA}

\section{Site 482 (Holes 482B, C, and D)}

Replicate analyzed whole-rock samples show considerable scatter in comparison to the glasses analyzed from equivalent stratigraphic intervals. These data are representative of Site 482 Chemical Types A, B, D, E, and $\mathrm{F}$ and show compositional relationships which are similar to those shown by the shipboard data. In general, the greater variability of the whole-rock data is attributed to intraflow unit inhomogeneity resulting from differential phenocryst distribution, together with the effects of preeruption fractional crystallization. Petro-
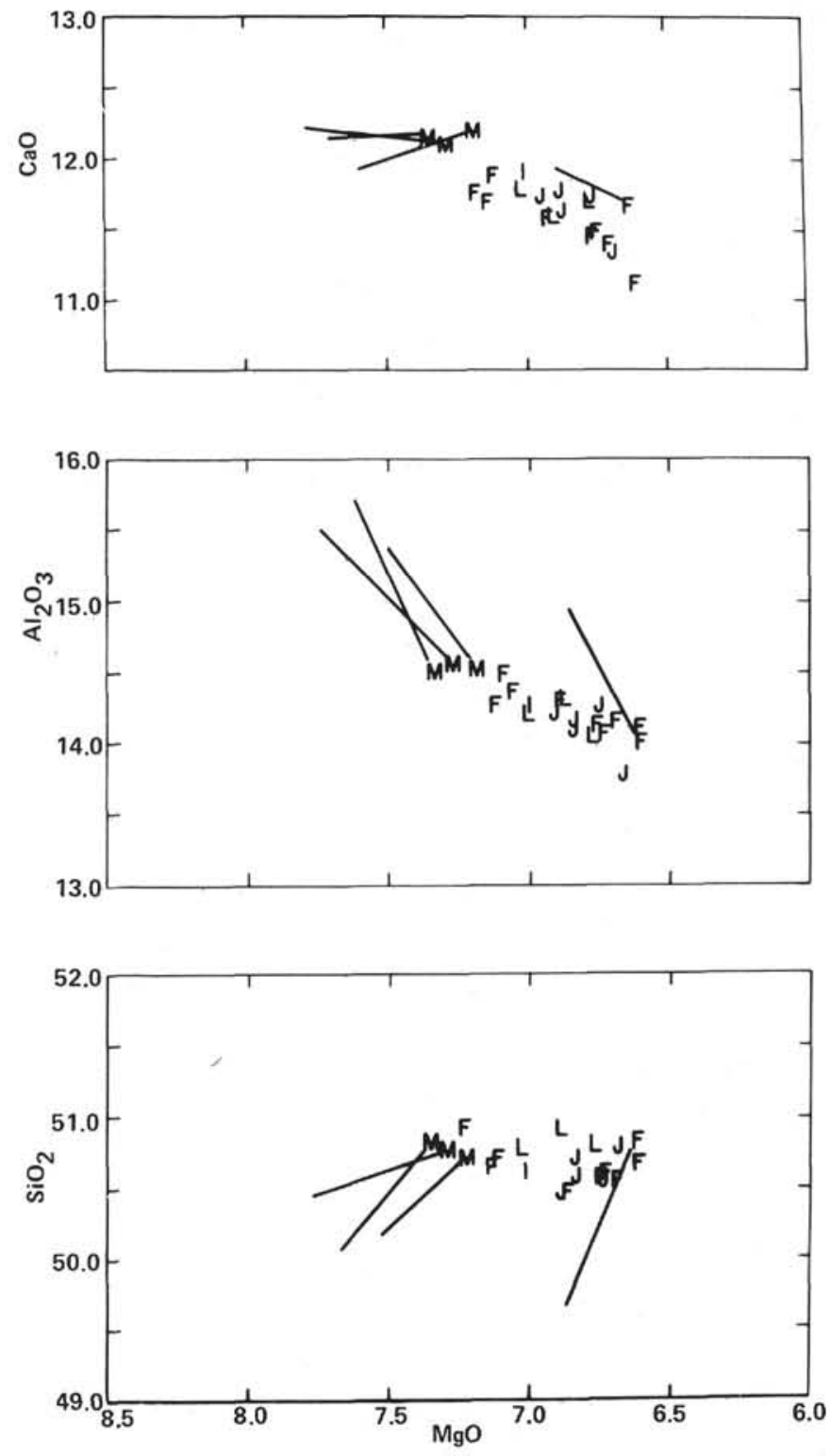

according to equivalent whole-rock chemical type, Site 483 . (Tie-lines con-

graphic studies of the samples prior to fusion confirm the characteristics defined for the samples in each of the shipboard chemical types.

Two broad chemical groupings may be distinguished on the basis of oxide variations: $\mathrm{A}$ and $\mathrm{D}$, reflecting a high $\mathrm{TiO}_{2}$ content, and $\mathrm{B}, \mathrm{E}$, and $\mathrm{F}$ reflecting a low $\mathrm{TiO}_{2}$ content for equivalent $\mathrm{MgO}$ content. Types $\mathrm{D}$ and $\mathrm{B}$ appear to be related respectively to Types $A$ and $E$ by variable but small amounts of phenocryst accumulation.

The discrimination of chemical types by means of microprobe data is not particularly good, however. While the data are qualitatively consistent with both the original chemical groupings observed on shipboard and with their respective petrographic characters, a comparison of microprobe to shipboard XRF data suggests that a larger data base is required for representative coverage of the compositional variation. 


\section{Site 483 (Holes 483 and 483B)}

Three whole-rock samples from this site were analyzed, one from the massive unit represented by Chemical Type D (Hole 483) and two from massive units corresponding to Chemical Type $\mathrm{H}$ (Holes 483 and 483B). The oxide variation shows good correspondence with the shipboard XRF data for the Type $\mathrm{H}$ unit, but the Type D sample (Sample 400) is considerably more $\mathrm{Al}_{2} \mathrm{O}_{3}$ rich and $\mathrm{MgO}$-poor than shipboard-analyzed samples from the same cooling unit. The difference corresponds to a relative enrichment of plagioclase in the microprobe-analyzed samples. No accumulative plagioclase was noted during petrographic studies, and the variation may reflect relict plagioclase remaining after fusion. However, other chemical studies show similar $\mathrm{Al}_{2} \mathrm{O}_{3}$-rich trends for this unit (Flower 1980). In contrast, Type $\mathrm{H}$ samples correspond well to the shipboarddefined variation for this type.

\section{Site 485 (Hole 485A)}

Samples for microprobe analysis were taken from the lower lithologic units drilled at this site, which, with the exception of Unit 5, were not analyzed on shipboard. Chemical types as such were not identifiable for the basalts from Site 485 , although we refer to the chemical identity of each lithologic unit as A (Lithologic Unit 1), $\mathrm{B}(2), \mathrm{C}(3)$, etc. The microprobe data indicate a relative enrichment of $\mathrm{Al}_{2} \mathrm{O}_{3}$ in Unit $8(\mathrm{H})$, the lithology of which reflects slightly greater abundance of phenocryst plagioclase. Unit 5 (E) shows internal petrographic variation, suggesting re-sorting of plagioclase phenocrysts during and after emplacement of the unit. Otherwise, the overlap of oxide variations for Units $5(\mathrm{E})$ and $6(\mathrm{~F})$, analyzed by microprobe, and 1 (A), 2 (B), and 3 (C), analyzed by XRF on shipboard, appears to indicate that they were derived from similar, probably identical, high-level sources. This conclusion is also consistent with their sparsely to moderately phyric lithology.

\section{LIQUID VARIATION AT SITES 482 AND 483}

The microprobe data presented here may be used for generalized conclusions about whole-rock chemical variation. Glass and whole-rock data obtained for several aphyric cooling units on shipboard best show the variations in composition of the liquid magmas emplaced during crustal construction at Sites 482 and 483 . The liquid variation at these sites appears to reflect simple cotectic fractionation patterns, suggesting fractional crystallization in a near-surface, subaxial environment. Individual erupted magma batches, while adhering to the overall trend, appear to have been derived from discrete parent batches, as suggested by discrepancies in their $\mathrm{TiO}_{2}$ and $\mathrm{P}_{2} \mathrm{O}_{5}$ contents.

The basalt chill rinds at Sites 482 and 483 are consistently more fractionated (i.e., more $\mathrm{TiO}_{2}$ - and $\mathrm{FeO}$ rich) than the associated bulk-rock compositions, even for aphyric cooling units with compositions similar to that of the erupting lava. The glass and whole-rock data usually approximate the overall liquid-type fractionation trend, despite the generally greater scatter of the whole-rock data. This pattern is in contrast to that observed for Atlantic Ocean basalts, where complex phenocryst redistribution patterns involve (notably) the strong accumulation of plagioclase (e.g., Staudigel et al., 1980; Flower et al., 1977, 1980; Byerly and Wright, 1978). There are slight but probably significant systematic differences between the Site 482 and Site 483 glass compositional trends. It is perhaps of greater significance that no distinction is apparent between the oxide variation observed in these glasses and that observed in the glasses from some Atlantic basement localities (e.g., Sites 417 and 418 in Cretaceous Atlantic crust; Byerly and Sinton, 1980). These comparisons, to be discussed fully elsewhere, may be interpreted as a remarkable indication of the homogeneity of ocean ridge tholeiites. However, considered in light of the variations noted between liquid fractions at different localities (e.g., Bryan and Dick, 1979), it merely demonstrates the lack of systematic differences in composition between liquid magmas generated at "fast" versus "slow" spreading ridges.

\section{ACKNOWLEDGMENTS}

The authors acknowledge the support of the DSDP staff, the Global Marine crew, and all who ensured the success of Leg 65. We thank Peter Jezek, Gene Jarosewich, and Joe Nelen of the U.S. National Museum of Natural History (Dept. of Mineral Sciences) for their help in various stages of the analytical work.

\section{REFERENCES}

Bryan, W. B., and Dick, H. J. B., 1979. Contrasted liquidus variation trends in sea floor basalt glasses. Eos Trans. Am. Geophys. Union, 60 .

Bryan, W. B., Thompson, G., and Frey, F. A., 1979. Petrologic character of the Atlantic crust from DSDP and IPOD drill sites. In Talwani, M., Harrison, C. G., and Hayes, D. E. (Eds.), Sec. Maurice Ewing Series, (Am. Geophys. Union Spec. Publ.), pp. 273-284.

Byerly, G. R., and Sinton, J. A., 1980. Compositional trends in natural basaltic glasses from DSDP Holes 417D, 418A, B. In Donnelly, T., Francheteau, J., Bryan, W., Robinson, P., Flower, M., Salisbury, M., et al., Init. Repts. DSDP, 51, 52, 53, Pt. 2: Washington (U.S. Govt. Printing Office), 957-972.

Byerly, G. R., and Wright, T. L., 1978. Origin of major element chemical trends in DSDP Leg 37 basalts, Mid-Atlantic Ridge. $J$. Volcanol. Geotherm. Res., 3:229-279.

Flower, M. F. J., Robinson, P. T., Ohnmacht, W., Marriner, G., and Schmincke, H.-U., 1980. Lithologic and chemical stratigraphy at DSDP Sites 417 and 418. In Donnelly, T., Francheteau, J., Bryan, W., Robinson, P., Flower, M., Salisbury, M., et al., Init. Repts. DSDP, 51, 52, 53, Pt. 2, Washington (U.S. Govt. Printing Office), 939-956.

Flower, M. F. J., Robinson, P. T., Schmincke, H.-U., and Ohnmacht, W., 1977. Magma fractionation systems beneath the MidAtlantic Ridge, $36-37^{\circ}$ N. Contr. Mineral. Petrol., 64:167-195.

Jezek, P. A., Sinton, J. M., Jarosewich, E., and Obermeyer, C. R., 1979. Fusion of rock and mineral powders for electron microprobe analysis. Smithson. Contrib. Earth Sci., 22:46-52.

Melson, W. G., 1979. Chemical stratigraphy of Leg 45 basalts: Electron probe analysis of glasses. In Melson, W. G., Rabinowitz, P.D., et al., Init. Repts. DSDP, 45: Washington (U.S. Govt. Printing Office), 507-512.

Melson, W. G., Vallier, T. L., Wright, T. L., et al., 1975. Chemical diversity of abyssal volcanic glass erupted along Pacific, Atlantic, 
and Indian Ocean seafloor spreading centers. The Geophysics of the Pacific Ocean and its Margins: Washington, D. C. (Am. Geophys. Union, Geophys. Monogr. Series).

Staudigel, H., Bryan, W. B., and Thompson, G. 1980. Chemical variation in glass-whole-rock pairs from individual cooling units in Holes 417D and 418A. In Donnelly, T., Francheteau, J., Bryan, W., Robinson, P., Flower, M., Salisbury, M., et al., Init. Repts.
DSDP, 51, 52, 53, Pt. 2, Washington (U.S. Govt. Printing Office), 977-986.

Thompson, R. N., 1980. Major element chemistry of basaltic glasses in Hole 418A lavas and a dyke: DSDP Legs 52 and 53. In Donnelly, T., Francheteau, J., Bryan, W., Robinson, P., Flower, M., Salisbury, M., et al., Init. Repts. DSDP, 51, 52, 53, Pt. 2, Washington (U.S. Govt. Printing Office), 973-976.

APPENDIX

Cross-Reference of Our Sample Numbers to DSDP Sample Numbers, Inferred Lithologic Units, and Chemical Types

\begin{tabular}{|c|c|c|c|c|}
\hline Sample No. & $\begin{array}{l}\text { DSDP Sample } \\
\text { (interval in } \mathrm{cm} \text { ) }\end{array}$ & $\begin{array}{l}\text { Lithologic } \\
\text { Unit }\end{array}$ & $\begin{array}{c}\text { Chemical } \\
\text { Type }\end{array}$ & Phenocrysts \\
\hline \multicolumn{5}{|c|}{ Analyzed glass selvedges } \\
\hline 30 & $482 \mathrm{~B}-14-1,90-94$ & 1 & A & \\
\hline 50 & $482 \mathrm{~B}-14-2,136-140$ & i & ?F & \\
\hline 210 & $482 \mathrm{D}-10-3,88-91$ & 3 & $\mathrm{~F}$ & \\
\hline 220 & 482D-10-3, 93-97 & 3 & $\mathrm{~F}$ & \\
\hline 230 & $482 \mathrm{D}-10-3,130-135$ & 3 & $\mathrm{~F}$ & \\
\hline 250 & $482 \mathrm{D}-11-2,33-38$ & 3 & $\mathrm{~F}$ & \\
\hline 260 & $482 \mathrm{D}-11-3,19-22$ & 3 & $\mathrm{~F}$ & \\
\hline 290 & $482 \mathrm{~F}-11,-1,24-28$ & 1 & A? & \\
\hline 310 & $483-20-1,105-109$ & 6 & $\mathbf{F}$ & \\
\hline 330 & $483-21-2,33-38$ & 6 & F & \\
\hline 340 & $483-22-1,73-77$ & 6 & F & \\
\hline 350 & $483-22-1,125-127$ & 6 & $\mathrm{~F}$ & \\
\hline 360 & $483-22-2,20-24$ & 6 & $\mathrm{~F}$ & \\
\hline 370 & $483-23-2,115-119$ & ? & F & \\
\hline 400 & $483 \mathrm{~B}-12-1,87-89$ & 5 & $i$ & \\
\hline 410 & $483 \mathrm{~B}-13-2,87-89$ & 5 & $\mathrm{~F}$ & \\
\hline 420 & $483 \mathrm{~B}-13-3,49-52$ & 5 & $\mathrm{~F}$ & \\
\hline 430 & $483 \mathrm{~B}-14-2,51-53$ & 5 & F & \\
\hline 450 & $483 \mathrm{~B}-21-2,1-4$ & $7 \mathrm{~b}$ & $\mathrm{j}$ & \\
\hline 460 & $483 \mathrm{~B}-22-2,100-101$ & $7 \mathrm{~b}$ & $\mathrm{j}$ & \\
\hline 470 & $483 \mathrm{~B}-23-1,20-23$ & $7 \mathrm{~b}$ & j & \\
\hline 480 & $483 \mathrm{~B}-23-3,90-96$ & $7 \mathrm{~b}$ & $\mathrm{j}$ & \\
\hline 490 & $483 \mathrm{~B}-24-1,81-84$ & $7 \mathrm{~b}$ & J & \\
\hline 500 & 483B-29-1, 91-93 & 9 & L & \\
\hline 510 & $483 \mathrm{~B}-30-1,50-52$ & 9 & $\mathrm{~L}$ & \\
\hline 520 & 483B-30-1, $95-99$ & 9 & $\vec{L}$ & \\
\hline 530 & $483 \mathrm{~B}-31-1,96-98$ & 9 & 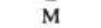 & \\
\hline 540 & $483 \mathrm{~B}-31-3,16-19$ & 9 & M & \\
\hline 550 & $483 \mathrm{~B}-32-2,20-26$ & 9 & M & \\
\hline \multicolumn{5}{|c|}{ Analyzed whole-rock samples (this work) } \\
\hline 10 & $482 \mathrm{~B}-13-2,37-42$ & 1 & A & Aphyric \\
\hline 40 & $482 \mathrm{~B}-14-2,106$ & 1 & $\mathrm{~F}$ & Aphyric \\
\hline 60 & $482 \mathrm{~B}-15-1,9-12$ & $i$ & ? & Aphyric \\
\hline 70 & $482 \mathrm{~B}-16-1,10-15$ & 2 & B & Plagioclase* \\
\hline 80 & $482 \mathrm{~B}-18-1,18-13$ & 3 & B & Plagioclase* \\
\hline 90 & $482 \mathrm{~B}-20-2,88-90$ & 5 & D & Plagioclase ${ }^{*}$ and clinopyroxene \\
\hline 110 & $482 \mathrm{~B}-21-3,55-57$ & 7 & D & $\begin{array}{l}\text { Plagioclase }{ }^{*} \text { and clinopyroxene } \\
\text { and olivine }{ }^{*}\end{array}$ \\
\hline 120 & $482 \mathrm{~B}-23-1,20-22$ & 7 & D & $\begin{array}{l}\text { Plagioclase* and clinopyroxene* } \\
\text { and olivine* }\end{array}$ \\
\hline 160 & $482 \mathrm{C}-12-1,120-121$ & 2 & B & Plagioclase* \\
\hline 180 & $482 \mathrm{C}-15-1,117-120$ & 2 & B & Plagioclase ${ }^{*}$ and clinopyroxene ${ }^{*}$ \\
\hline 190 & $482 \mathrm{D}-10-3,58-60$ & 2 & $\mathrm{E}$ & $\begin{array}{l}\text { Plagioclase* and clinopyroxene } \\
\text { and olivine }\end{array}$ \\
\hline 200 & $482 \mathrm{D}-10-3,68-72$ & 3 & F & Aphyric \\
\hline 240 & $482 \mathrm{D}-11-1,69-74$ & 3 & $\mathrm{~F}$ & Aphyric \\
\hline 270 & $482 \mathrm{D}-12-2,64-71$ & 4 & B & Plagioclase \\
\hline 300 & $483-17-1,19-21$ & 4 & D & Plagioclase* \\
\hline 380 & $483-26-1,54-56$ & 7 & $\mathrm{H}$ & Plagioclase ${ }^{*}$ and olivine* \\
\hline 440 & $483 \mathrm{~B}-17-1,13-16$ & 6 & $\mathrm{H}$ & Plagioclase and olivine* \\
\hline 570 & $485 \mathrm{~A}-32-3,57-62$ & s & $\mathrm{i}$ & Aphyric \\
\hline 590 & $485 \mathrm{~A}-33-1,127-132$ & 5 & i & Aphyric \\
\hline 600 & $485 A-33-2,85-88$ & 5 & i & Aphyric \\
\hline 610 & $485 \mathrm{~A}-34-1,121-126$ & 6 & j & Plagioclase and olivine ${ }^{*}$ \\
\hline 630 & $485 A-35-6,39-44$ & 6 & J & Plagioclase and olivine* \\
\hline 640 & $485 \mathrm{~A}-38-4,102-107$ & 8 & L & Plagioclase \\
\hline 660 & $485 \mathrm{~A}-39-5,39-43$ & 8 & L & Plagioclase \\
\hline
\end{tabular}

Note: $\boldsymbol{\bullet}^{\boldsymbol{n}}$ trace. 